Danijela ZDRAVKOVIĆ

УДК 316.728 (497.11-12 Трговиште):796

Siniša STOJANOVIĆ

- прегледни научни рад -

Pedagogical faculty in Vranje

University of Niš

Zvezdan SAVIĆ

Faculty of Sport and Physical Education

University of Niš

\title{
A YOUNG SPORTSMAN ABOUT LIFE OPPORTUNITIES AND SPORTS IN RURAL AREAS OF SOUTH SERBIA - QUALITATIVE APPROACH (MUNICIPALITY OF TRGOVIŠTE)*
}

\begin{abstract}
The work appeared from the need to draw attention to the social position of young sportspeople, and to emphasize the importance of socialization of young rural population for the revitalization of the border area of South Serbia. In the introductory part of the work, we talk about the researched border area of South Serbia, which developed during the 20th century under a strong influence of wider social, political, and economic factors, which determined its demographic development. Thanks to this, the population of the border area entered the $21^{\text {st }}$ century with three long-term demographic processes, namely: a total depopulation (decrease in the number of citizens), natural depopulation (death rate higher than birth rate), and demographic ageing, along with prominent effects of deindustrialization. Subject of research: The authors examined the phenomenon of the preservation of the identity of local population in the border municipality Trgoviste, studying how young sportspeople who live in villages feel about their belonging to society. This sense of belonging depends on four systems of social inclusion (Jentasch and Shucksmith 2004). The examined border municipality is in the far southeast of the Republic of Serbia, next to the border with Macedonia, and it borders the municipalities of Bosilegrad, Vranje and Bujanovac. Work methodology: In the work the authors applied the qualitative style of research, and the data were collected by applying the methodological ,Instructions and Procedures for Collecting Data in Border Municipalities of Eastern and Southeastern Serbia“ prepared as part of the project ,, Sustainability of the Identity of Serbs and National Minorities in the Border Municipalities of Eastern and Southeastern Serbia " (OI 179013), realized at the University of Nis - Faculty of Mechanical Engineering, and funded by the Ministry of Education, Science and Technological Development of the Republic of Serbia.
\end{abstract}

\footnotetext{
* The paper is the result of research within the project: „Sustainability of identity of Serbs and ethnic minorities in the border municipalities of East and Southeast Serbia" (OI 179013), carried out at theUniversity of Nis - Faculty of Mechanical Engineering and funded by the Ministry of Education, Science andTechnological Development of Republic of Serbia.
} 
Research results: The work focuses on the advantages and disadvantages of living in a rural community of Trgoviste Municipality from the viewpoint of a young rural inhabitant (Marko Trajkovic, a student of the University of Nis). By using a deep interview, the author selected some sociological characteristics related to lifestyle and limitations in plans for the future in the examined rural area. By recognizing the current demographic, social, and economic trends, ethnic and educational diversity in South Serbia border area, the author got down to examining the quality of everyday life of young people, who represent one of the more vital factors of the renewal of the development of villages in border rural areas. Conclusion: Through research, we have determined that life expectations of young inhabitants of the researched rural area are formed through their own attitudes to village as a favorable (or unfavorable) framework for realizing their life ambitions. Despite the modest participation of young people in Trgoviste, they are full of optimism. It is exactly that social and human capital which should be used. We are left with a hope that this modest contribution will initiate necessary research of lifestyles of youth in border areas of South Serbia, with a tendency of improving the quality of life of young people and achieving more favorable socio-economic preconditions for renewal of these areas in the new wave of modernization of the Republic of Serbia.

Key words: renewal of villages, a student of the Faculty of Sport and Physical Education, Trgoviste, Marko Trajkovic.

\section{Introduction}

During the $20^{\text {th }}$ century, the border area of South Serbia developed under a strong influence of wider social, political, and economic factors, which determined its demographic development. Due to this, the population of the border area entered the $21^{\text {st }}$ century with three long-term demographic processes, namely: a total depopulation (decrease in the number of inhabitants), natural depopulation (death rate higher than birth rate), and demographic ageing, along with prominent effects of deindustrialization. The demographic changes in the south border area of the Republic of Serbia - namely, the cruel economic changes in the Municipality of Trgovište brought about a total economic collapse, and a transformation in the economic development of the researched area. In the last years, South Serbia has been in very unfavorable conditions and has been facing obstacles which block its social development, which was partially caused by a drastic decrease in the total number of rural population at the end of the $20^{\text {th }}$, and the beginning of the $21^{\text {st }}$ century, people leaving certain rural areas, and the drop in the fertility potential of the whole area.

The numerous and various problems which accompany the social development of border municipalities of South Serbia today cannot be perceived only through the prism of its current conditions, but also through the lenses of its relations towards cultural tradition. The rural areas of the Republic of Serbia cover the larger part of its complete territory, and social, economic, and demographic conditions contribute to the underdevelopment of these areas, which has 
accelerated the processes of migration from villages to towns in the last twenty years, with the effects of transition displayed in the processes of rural deindustrialization and depopulation.

The effects of the process of deindustrialization are quite visible in rural areas of South Serbia because these run-down industrial facilities, with weakened capacities, made it impossible for this area to develop and flourish in the sense of providing employment, family planning, and total social development. That also opens a lot of questions regarding the sustainability of rural areas, and the possibility of their recovery and renewal. The basic elements of the survival of villages are connected to the sphere of ecological, cultural, and socio-economic sustainability in tandem with the social and human capital of this area.

Through a sociological observation of a rural area (Trgovište Municipality) and from a micro sociological perspective, in this work we will try to identify some of the characteristics of the rural area and the needs to revitalize this area in the border region of Serbia, at the same time promoting the necessary measures for development and actions that should be undertaken in due time to achieve this. We will create an experiential research base based on the technique of collecting the basic data on the village Trgovište according to the Reminder for Collecting Material (Participation of Inhabitants in the Renewal and Development of Villages, 2011), made under the guidance of Dr Đura Stevanović in the Belgrade Institute for Village Studies, Serbian Association for Rural and Agricultural Sociology, and Balkan Association for Rural and Agricultural Sociology.

The authentic tradition and the differences based on it in the researched cultural space (Trgovište Municipality) offer a significant contribution to sociological research into lifestyles of young people from different theoreticalanalytic approaches, and the conception of an analytical framework for a sociological research into lifestyles of youth in border areas - qualitative approach. The subject of our research is the study of the phenomenon of the preservation of identity of local population in the border Municipality of Trgovište, checking how young village people feel about their belonging to society. The sense of such belonging depends on four systems of social inclusion, namely: integration in civil society (the idea of equality, free access of citizens to information and centers of political power); then, integration in the market (employment, ability for self-employment etc.); as well as integration in society (possibility to participate in state social programs without the danger of being stigmatized) and finally, interpersonal integration (family, friends and neighbors' networks, as well as social networks which provide help to people in trouble, socialization and moral support) (Jentasch and Shucksmith 2004). The examined border municipality is in the far southeast of the Republic of Serbia, next to the border with Macedonia, and it borders the municipalities of Bosilegrad, Vranje and Bujanovac.

The border area of South Serbia with its environs is an interesting area for research. For a long time, in this area or close to it, there have been different social movements of inhabitants (migrations, rearrangement of state borders). In this important geographic area, there has been a continual process of geographic 
rearrangement with the aim of creating a more complete urban network. Blending of different cultures and different political influences takes place in this area thanks to its geostrategic and geopolitical position.

\section{About Trgovište - on the margins of Serbia society}

The categorization of 37 municipalities given in the Strategy of Regional Development of the Republic of Serbia for the period of 2007-2012 (Official Gazette, no. 21/07) was used as the starting point for sociological research, current issues and scientific importance of studying the issue of living next to the border and the sustainability of national identity in south border region (the Municipality of Trgovište). The underdeveloped areas were divided into two groups: economically underdeveloped and demographically endangered municipalities. The Municipality of Trgovište is in the group of economically underdeveloped areas, along with 28 other municipalities which got the same status according to the following criterion - the income in those municipalities is under $50 \%$ of average national income, and they have been experiencing economic, social, and demographic problems in the last twenty years. According to the Regulation on Determining a Uniform List of the Development State of Regions and Units of Local Self-government (Official Gazette, no. 62/2013), the Municipality of Trgovište belongs to the fourth group of severely underdeveloped units of local self-government whose percentage of development is under $60 \%$ of national average. The achieved national income and investment per capita in Trgovište do not reach even $1 / 3$ of average national income per capita in Serbia.

The researched border municipality has always been on the margins of economic development of Serbian society, and has been categorized as an underdeveloped region for a long time, and in 1988 it was put in the group of underdeveloped areas along with 16 other municipalities. By analyzing the rate of national income and the unemployment rate in the Municipality of Trgovište, we can notice the highest values in 1988, whereas the process of massive layoffs in the first decade of the $21^{\text {st }}$ century reached its peak in 2007 so we can clearly see that since 2001, the number of unemployed people has almost doubled.

Trgovište represents the biggest settlement of the Municipality of Trgovište, which consists of 35 settlements with 5,091 inhabitants according to the last census in 2011. There are 1413 inhabitants over 18 years old in the settlement, and the average age of the population is 37.5 years ( 36.9 for men and 38.1 for women). Trgovište is in the central part of the municipality.

The Municipality of Trgovište is in the far southeast of the Republic of Serbia, it occupies the area of $370 \mathrm{~km}^{2}$ next to the border with Macedonia, and borders the municipalities of Bosilegrad, Vranje and Bujanovac.

With every new census, the number of inhabitants in the Municipality of Trgovište grew a little bit, because the town of Trgovište, the largest settlement in the Municipality of Trgovište became home to people from villages in more inaccessible areas; however, there was a steep decline in the period after 
2011 Census (Place Table 1 here). This has, of course, influenced the number of pupils who attend the primary school in Trgovište, which will later be corroborated by historical data.

\section{On schooling system and education infrastructure in Trgovište}

Education is an important prerequisite for the development and progress in modern world. World countries which do not invest in the development of education cannot become a part of postmodern civilization, nor can they ensure their progress and development in the world global system. The modern scientific thought on education holds a view that the role of modern education consists of transforming the consciousness of people regarding the increasing integration of modern world and accepting the principle of interdependence, diversity, and tolerance. To that end, modern European society has organized school as a „public institution whose establishment and work is conducted under the conditions prescribed by law of every specific society/state" (Ivković, M., 2004:70).

Modern school in Serbia is a state institution of great importance, which is expected to reproduce ,a desirable system of values“" as a condition for social development. From the pedagogical viewpoint, it is an institutionalized form of education, and from the sociological viewpoint it is a state institution or an institution of society (Ivković, M., 2004:69) which influences social development. Social critics of the $20^{\text {th }}$ century thought that a traditional, closed school does not help socialization, thus not helping the acquisition of behaviors important for cognitive and social development of children either. Modern school is intended for socialization, but in Serbia education is also used to reproduce values dominant in the culture of Serbian society. „A hidden syllabus“ plays an important role in cultural reproduction, and the formal syllabus is only one part of a more general process of cultural reproduction which is under the influence of numerous informal aspects of learning, education, and school environment (Gidens, E. 2003:534). From this kind of theoretical perspective, we are going to examine the development of education, i.e. an overview of educational infrastructure in Trgovište in the context of historical development of this border area. The history of education is also often designated as the history of educational or pedagogic institutions (Ivković, M., 2004:60).

The first school in Trgovište was opened last century (in 1907). Education in Trgovište started with teaching in private houses with only one teacher, Milan Branković, in the school year 1914/15. The teaching process took place in the main school in Trgovište. During the war period from 1912 to 1918, there were no classes, like in other schools in Serbia at that time. The school resumed work in the school year 1914/15. „Children first started coming to school wanting to learn how to read and write in 1906. Parents, who realized the importance of literacy, organized classes for their children in private houses, with a wish to bring literacy to their children. Today, this is the biggest school in the municipality, with its 6 outposts. The students of this school achieve good results in school competitions, and they maintain the same results in high school. A large 
number of students who finished this school now hold Ph.D. and master's degrees, are highly educated people, who unfortunately do not return to their hometown. Due to population migration, the number of students decreases every year."

Hereafter we talk about the educational infrastructure according to the following levels: preschool institution, primary schools and high school.

The Preschool Institution „Poletarac“ is the only institution of this kind in the municipality. It also comprises the outposts of preparatory preschool program in Radovnica, Donji Stajevac and Novo Selo. There are 47 children in the institution, 43 of whom are of preschool age. The statistical picture of primary schools in the rural municipality of Trgovište (Place Table 2 here) consists of four schools with 10 outposts.

At the beginning of the third millennium, the most extensive works were done on the reconstruction of the school building from 2012 to 2013 - the school got the system of central heating and new joinery. In front of the school, towards the road, there is a big yard with arranged lawns decorated with roses, conifers, and other decorative plants. The teaching of physical education and sports activities like the Futsal Tournament take place on the nearby recreation area, near the river Pčinja.

The primary school „Branko Radičević“ in Trgovište consists of 13 classrooms, a library, a special music classroom, and a classroom for computer science and technical education, a room for after-school care, a kitchen, administrative premises, teachers' office, and a gym. There are 50 people employed in the school, 40 of whom are teachers. (Zdravković, D., Marković, M. i Jovanović, M. , 2016:38-43).

\section{Primary school ,, Vuk Karadžič“, Donji Stajevac}

According to the ethnographic - historiographic works of Jovan Hadži Vasiljević, a distinguished person from Vranje, the Primary school in Donji Stajevac started to work in 1840. The school worked in priests' houses, and the churchyard. The Turks considered it a religious institution, and thus tolerated it. So, the teachers and students would go to school dressed as priests - in mantles tied with a red belt, with a cross on their caps to show that they were clerical workers. In 1893, the school in Donji Stajevac had 38 students in the first grade. In the following school year 1893/94, there were 25 students in the first grade and 9 students in the second grade in the school in Donji Stajevac. In the school year 1894/95, the teacher Jovan Stevanović from Ranilug worked there. He organized the first celebration of St. Sava's Day as the school patron saint's day.

The school has well-preserved archives dated from 1920/21 until now, which is a rare occurrence in schools, so they can be used for concrete data not only about students, but the all-round work of the school. During the many years of its work, the school has been a beacon of education, and the keeper of Serbian national identity. At the initiative of the school director and the president of the Municipal Assembly of Trgovište at the time - Stojanče Stamenović, and with the wholehearted help of the Ministry of Education, and especially the minister Kaća Lazović, Ph.D. Professor, in 2000, Jovan Janjić, Ph.D. Professor, 
a long-term educational advisor for the Serbian language, wrote a monograph 160 Years of the Primary School in Donji Stajevac. 175 generations of young people from the Pčinja made first steps towards literacy in this school, and set off into life from there. All of them have this school in common, the school is something that connects them, make them belong to one family. Many people from that family, trained there, taught to be diligent and hard-working, have made significant contribution to the development of their birthplace, and others, who have left their birthplace, have participated in the social and economic life of other parts of Serbia, also with distinguished results and often responsible functions in social, economic, and other fields. (Zdravković, D., Marković, M. i Jovanović, M. , 2016:41-43).

\section{Primary School „Bora Stanković“, Novo Selo}

The Primary School „Bora Stanković“ in Novo Selo represents an educational institution located in Novo Selo. It also comprises several outposts in the villages: Barbace, Sajince, Margance and Petrovac. The school covers four local communities: Novo Selo and Sajince on the territory of Trgovište municipality, and Lepcinjce and Rusce on the territory of Vranje municipality. The central school in Novo Selo has four classes from grade 1 to 8 , two of which are combined classes, and four of which are not combined in higher grades. In the outposts, two classes are not combined at two different grades, and one is combined. The school area is hilly-mountainous, the villages are dispersed, so more than half of the students go to school on foot, some of them covering $10 \mathrm{~km}$ a day. There are not a lot of students who can use transportation to school. (Zdravković, D., Marković, M. i Jovanović, M. , 2016:41-43).

\section{Technical High School ,Milutin Bojić“ - Trgovište}

The Technical High School „Milutin Bojić" u Trgovistu was established in 1979 as an independent institution. Until 1979, the school worked as an outpost of the Educational Center „Vladimir Vujović - Vujo“ from Vranje.

During its existence, the school has educated students in common core studies, food technology, leather-working, and textile technology vocation. Since September $1^{\text {st }}$ 1993, the school educates students in the field of Trade for the educational profile of „Trader“, in the duration of three years.

Since the school year 2003/2004, the school has started educating students in the field of Economics for the educational profile of ,Economic technician", and the education for this profile lasts for four years. The functioning of this educational institution, and its existence, are of huge importance for the Municipality of Trgovište, as an underdeveloped region whose citizens live in unfavorable social conditions.

In that sense, huge efforts are being made to create better conditions for more effective functioning of this school, on the part of the people employed in the school, on one hand, and on the part of the local self-government, on the other hand. This contributes to a large progress in the field of education, educating professionals and keeping them on the territory of the municipality, or in a wider area, i.e. educating professionals not only for the needs of the Municipality of Trgovište. 
There are 25 employees in this only institution of high-school education. 21 of them are teachers, who work in five separate classes with 115 students (Place Table 3 here). There are three administrative workers: the school secretary, the chief of accounting, and an administrative worker. There are two auxiliary workers who take care about the hygiene in the school, and one worker who maintains the system of central heating.

When it comes to teachers, there are teachers of general-education subjects, and teachers of technical subjects (economists) (Zdravković, D., Marković, M. i Jovanović, M. , 2016:38-45).

\section{A work methodology and respondent}

In the work we applied the qualitative style of research - deep interview - as a methodologically useful research instrument in field research. The data were collected by applying the methodological Instructions and Procedures for Collecting Data in Border Municipalities of Eastern and Southeastern Serbia prepared as part of the project ,Sustainability of the Identity of Serbs and National Minorities in the Border Municipalities of Eastern and Southeastern Serbia " (OI 179013), realized at the University of Niš - Faculty of Mechanical Engineering, and funded by the Ministry of Education, Science and Technological Development of the Republic of Serbia. The obtained data were used for processing a young rural inhabitant, a sportsman, who, like many other people living in this area, struggles to survive in rough nature of the Pčinja region. He has chosen an original strategy for survival - he pursues further education as a full-time budget-financed student at the University of Niš. With the well-earned status of a budget-financed student upon passing the entrance exam for enrolling in the Faculty of Sport and Physical Education in Niš, he successfully acquires the required professional knowledge and skills with the highest honors and awards, which proved his choice. Education in the social context of revaluing the conditions of life and work is the condition of prosperous future in a border region, which is a rule proven by the story of the student and sportsman Marko Trajković, who proved himself at the age of 22 to be an exemplary young person in a border region through his determination, moderateness, diligence, and optimism.

\section{The empirical findings}

Rural areas in the south of Serbia must be modernized according to certain plans which will start with the state, possibilities and needs of individuals and society as a whole, when it comes to the renewal of villages. The villages in the south of Serbia are hit by a social-economic crisis which has the characteristics of undesirable spaces for living of people when it comes to modern individual and general needs. How to keep young professionals in the village? The renewal and development of villages must be viewed through the prism of social, cultural, economic, and demographic-political sphere. 
In the countries of the European Union, the renewal of villages is organized at three levels: national, regional, and municipal. Various experts are involved in interdisciplinary projects, after which local inhabitants are involved in the projects, and they review different types of data, and undertake activities in the spheres of agriculture, private entrepreneurship, cultural heritage, and tourism.

In Trgovište there is no initiative to do something about rural tourism, and the villages there have clean fresh air, unspoilt nature, rich cultural tradition, autochthonous cultivars of fruits and vegetables, lyrical poetry, interesting traditional costumes... The Monastery of St. Prohor of Pčinja is nearby, and the opportunities presented by religious tourism should be used to organize the meetings of local inhabitants with students, professionals, artists from urban areas, and thus alleviate the differences between villages and cities. This was done at the beginning of the $20^{\text {th }}$ century, when students of the High School „Bora Stanković" in Vranje went to visit rural areas accepting them as part of their country and culture. Rural tourism is important for the concept of sustainable development of a country because it sees natural characteristics and cultural tradition as sources of renewal and development. We should support rural tourism and rural education in Trgovište. The relevant issue regarding village renewal, especially the renewal of villages in border areas, is not only the economic, but also the social dimension of village life.

The local inhabitants, weekly migrants - students of this village call themselves highlanders whose families barely make ends meet. Our interviewee Marko Trajković talks about that. He is a successful student and sportsman of Trgovište, with the average grade of 10 in the school year 2014/15 (he received a special Certificate of Achievement from the University, Faculty of Sport and Physical Education, and a Certificate of Appreciation from the Municipality of Trgovište. He was raised in a family of teachers, his mother is a primary school teacher Vesna Trajković, who works in u Trgovište, in the Primary School „Branko Radičevićc“, and was born on July $8^{\text {th }}, 1968$ in the village of Lesnica, Trgovište Municipality. Marko Trajković's sister is a student of the Faculty of Medicine in Niš, and he finished High Medical School, Pharmacy Technician Program, with the highest honors, in Vranje. His father Goran (1965) was laid off after 20 years of work in the shoe making factory „Kostana“ in Trgovište. $\mathrm{He}$ is currently employed in a local private bakery SZR Kenedi.

The general data and short excerpts from the deep interview with our interviewee can be presented in the following order: he was born on February $4^{\text {th }}, 1995$ in Vranje. He successfully finished the Primary school „Branko Radičević" in Trgovište. During his primary school education, he displayed impressive results in knowledge, both at numerous competitions for checking the knowledge of natural and social science subjects, and sports competitions. From grade 1 to grade 8 of primary school, he participated in competitions and won a lot of medals, diplomas, certificates of appreciation at the following competitions: from grade 1 to grade 8 he won the total of 8 medals $(7$ gold ones and one silver medal) at the athletic (runner) competition called kros. A very important 
piece of information from Marko Trajković's childhood is that at the age of six he enrolled in ,a football school“ in the Football Club „Pčinja“, where he made his first steps in football. In the second grade, he won the second place in the poetry competition at the national level. This prize enabled him to have his name entered into the „Golden Book“, which comprises a list of the most renowned and talented poets and writers in Serbia. Throughout his whole education, he won multiple medals in different sports competitions (football, basketball, handball, athletics), and won numerous prizes at the following school competitions: second place in History competition at the national level, second place in Serbian language and literature at the national level, first place in the Latin language at the national level, third place in geography at the national level, etc.) He finished primary school with the average grade of 5,00. With this he earned the Diploma of Vuk Karadžić, which is given to the best students. After the High Medical School, Pharmacy Technician Program, completed in Vranje, he realized that sport and education were his future vocation. After successful preparation and swimming lessons, because he struggled with swimming as a person who had grown up in the mountains, he enrolled in the Faculty of Sport and Physical Education in Niš. Aware of his abilities and potentials, he undertook serious study work from the very start. Extracurricular activities and participation in the work of student organizations were one of the options to battle prejudices that he was just a student from an underdeveloped and remote region. Positive experiences during university studies have shown him that permanent work is the only condition for success. Due to this, he completed first year with the average grade of 10,00, and he was awarded as the best student of his generation a monetary award at the Solemn academy on the occasion of the Day of the Faculty in 2015. The faculty recognized his abilities, and rewarded his efforts in studying, which enforced his place in young student population promoted as the best at the Faculty. It is also important to mention that in 2015 his birthplace also presented him with a monetary award and a special certificate of appreciation on the Day of the Liberation of the Town, celebrated by the Municipality of Trgovište on September $15^{\text {th }}$. They rewarded him as the only student on the territory of the Municipality of Trgovište with the average grade of 10,00. First the Faculty, and then his birthplace, recognized his efforts, determination, diligence, and competitive spirit as a potential that should be motivated by awards to actively participate in due time in the renewal and development of his birthplace, as a professional and participant in progressive work.

The interviewee himself gathered that the most important activity to stop people migrating from this area and start its renewal is the investment in village infrastructure and creation of better conditions of life, by increasing work opportunities especially for young people, improving sports activities, including young people in social life, and the preservation of cultural heritage and tradition in the sense of building monuments. Marko points out that agriculture in the village is not critical when it comes to the migration of people from 
village into town, because in the last twenty years in Trgovište there has been a change in the age structure. Large portions of land are held by aging households, which have transformed themselves into consumer households. The demographic changes in the south border area of the Republic of Serbia namely, the cruel economic changes in the Municipality of Trgovište brought about a total economic collapse, and a transformation in the economic development of the researched area. In the last years, South Serbia has been in very unfavorable conditions and has been facing obstacles which block its social development, which was partially caused by a drastic decrease in the total number of rural population at the end of the $20^{\text {th }}$, and the beginning of the $21^{\text {st }}$ century, people leaving certain rural areas, and the drop in the fertility potential of the whole area. The social support of the state is necessary for the improvement of the demographic picture, because people bring about changes. Trgovište should see the opening of textile and lumber industry plants, and religious and sports tourism should be promoted.

In the opinion of Marko Trajković, a second-year student of the Faculty of Sport and Physical Education in Niš, the future of this village depends on its inhabitants, the local self-government, and the national politics. This practically means that the renewal and development of villages should be strategically planned to meet the needs, state and possibilities of individuals, region, and the state.

We got quite unexpected answers to our questions, which helped us process the phenomenon of the preservation of identity of young local population in the border municipality of Trgovište, studying how this young man feels about life in the village, and his belonging to society. The sense of such belonging depends on four systems of social inclusion, namely: integration in civil society (the idea of equality, free access of citizens to information and centers of political power); then, integration in the market (employment, ability for selfemployment etc.); as well as integration in society (possibility to participate in state social programs without the danger of being stigmatized) and finally, interpersonal integration (family, friends and neighbors' networks, as well as social networks which provide help to people in trouble, socialization and moral support) (Jentasch and Shucksmith 2004). His affirmative answers illustrated by examples from his experience in education, social life, professional development, parental and family support, have proved that the researched border municipality is in the processes of retraditionalization when it comes to two systems of social inclusion: integration in society (possibility to participate in state social programs without the danger of being stigmatized), and interpersonal integration (family, friends and neighbors' networks, as well as social networks which provide help to people in trouble, socialization and moral support). This student has a divided sense of belonging to society because the remaining two systems of social inclusion have remained uncovered in his case and the case of his fellow citizens. That is why there is a problem of the preservation of identity of local population in the border municipality of Trgovište. However, youth always carries creative energy and optimism, and Marko plans to return to his birthplace in order to contribute to the development of this poor area. 
In the work we applied the qualitative style of research, and in the methodological sense, it represents the application of the method of case study in combination with some other techniques, first and foremost interviewing (questionnaire, deep interview, field examination). The majority of data related to the objects of infrastructure were gathered based on a questionnaire prepared in advance.

The data were collected by applying the methodological Instructions and Procedures for Collecting Data in Border Municipalities of Eastern and Southeastern Serbia prepared as part of the project „Sustainability of the Identity of Serbs and National Minorities in the Border Municipalities of Eastern and Southeastern Serbia“ (OI 179013), realized at the University of Niš Faculty of Mechanical Engineering, and funded by the Ministry of Education, Science and Technological Development of the Republic of Serbia. The obtained data were used for processing a young rural inhabitant, a sportsman, who, like many other people living in this area, struggles to survive in rough nature of the Pčinja region. He has chosen an original strategy for survival - university education at the Faculty of Sport and Physical Education with the highest honors and awards, which proved that he wants to strategically invest in the creation of his identity. Education in the social context of revaluing the conditions of life and work is the condition of prosperous future in a border region.

This experiential note about Marko Trajković from Trgovište, a fulltime student of the Faculty of Sport and Physical Education in Niš is a proof that professional competences and providing means for a scientific-technological revolution in the most underdeveloped region is one of the prerequisites of recovery of South Serbia.

The work focuses on the advantages and disadvantages of living in a rural community of Trgovište Municipality from the viewpoint of a young rural inhabitant (Marko Trajković, a student of the University of Niš). By using a deep interview, we selected some characteristics related to life opportunities and limitations in the examined rural area. By recognizing the current demographic, social, and economic trends, ethnic and educational diversity in South Serbia border area, the author got down to examining the quality of everyday life of young inhabitants, who represent one of the more vital factors of the renewal of the development of villages in border rural areas.

\section{Conclusion}

While examining latent social phenomena, like sport in rural areas, the quality of life of young people in rural areas or lifestyles of youth in villages, seen through social participation in border areas, one should bear in mind the fact that all cultural processes and educational trends have their developmental dimension, and apart from that, some of them cannot be scientifically studied in an all-round way, in vivo, and are only accessible for researchers when they are presented in the way of value orientations and beliefs of interviewees, with the aim to use the gathered data for scientific purposes. To that end, we organized an interview with a chosen student from the south border zone, bearing in mind that those beliefs of individuals do not always present an objective description of the situation they are related to. 
Through research, we have determined that life expectations of young village inhabitants are formed through their own attitudes to rural area as a favorable (or unfavorable) framework for realizing their life ambitions, through systems of social inclusion. Despite the modest participation of young people in Trgovište, they are full of optimism, and that social and human capital should be used. We are left with a hope that this modest contribution will initiate necessary research of social life in border areas of Serbia, with a tendency of improving the quality of life of young people and achieving the prerequisites for the revitalization of these areas.

The paper represents a contribution to the research into a social role and importance of individuals and transformation of lifestyles in the social life of the border areas of South Serbia. Social life in the border areas viewed from the aspects of economic survival and the return of young educated people from university urban centers to rural areas of the border region, requires further scientific examination with a realistic assessment that the sustainability of life and work in the researched area can only be provided by investing in human resources and the exploatation of natural resources within the boundaries of sustainability.

\section{References}

1. Vukotić, V. i dr. (2013). Obrazovanje i razvoj. Beograd: Institut društvenih nau$\mathrm{ka}$, Centar za ekonomska istraživanja.

2. Gidens, E. (2003). Sociologija. Beograd: Ekonomski fakultet u Beogradu.

3. Zdravković, D., Marković, M. i Jovanović, M. (2016). Obrazovni resursi u pograničju istočne i jugoistočne Srbije. Niš: Mašinski fakultet Univerziteta u Nišu: JUNIR, Novi Sad: Prometej.

4. Zdravković, D. (2014). Socijalni kontrasti u pograničju (opština Trgovište). Beograd: Zadužbina Andrejević.

5. Здравковић, Д. (2014). Рефлексивни практичар у пограничју - учитељица Весна Трајковић (Трговиште), у: Учитељь у пограничју источне и југоисточне Србије, приредиле Марија Јовановић, Данијела Здравковић и Весна Трифуновић, 31-56. Ниш: Филозофски факултет у Нишу.

6. Здравковић, Д. (2014). Методика наставе математике: универзитетски професор Тодор Малиновић (Трговиште), у: Узорник у пограничју источне и југоисточне Србије, приредили Драгољуб Б. Ђорђевић, Весна Трифуновић и Његош Драговић, стр. 289-309. Нови Сад и Ниш: Прометеј и Машински факултет у Нишу.

7. Златановић, М. (2007). Пчиња. Врање: Врањске књиге.

8. Ивковић, М. (2004). Сочиологија образовања - одабране теме. Врање: Учитељски факултет у Врању.

9. Tvendž, Dž. (2013). Generacija JA. Podgorica: CID.

10. Todorova, M. (1999). Imaginarni Balkan. Beograd: Biblioteka XX vek.

11. Трифуновић, В. (2006). Породииа и школа. Јагодина: Учитељски факултет у Јагодини. 
12. Трифуноски, Ј. (1962). Врағска котлина (антропогеографска испитиваға), Посебна издања књига 12, Скопје: Природно-математички факултет Скопје.

13. Станојевић, Д., Здравковић, Д. (2013). Школа и друштвене промене. Novo mesto: Pedagoška obzorja.

14. СТАНОВНИШТВО. Упоредни преглед броја становника од 1948-2011. Подаци по насељима, Књига 1, Београд.

15. Cvijić, J. (1991). Antropogeografski i etnografski spisi. Beograd: SANU - ZUNS.

\section{Legends}

Table 1 Demography ${ }^{1}$ of Trgovište

\begin{tabular}{|c|c|}
\hline Year & Population \\
\hline 1948 & 820 \\
\hline 1953 & 840 \\
\hline 1961 & 921 \\
\hline 1971 & 972 \\
\hline 1981 & 1041 \\
\hline 1991 & 1787 \\
\hline 2002 & 1866 \\
\hline 2011 & 1716 \\
\hline
\end{tabular}

${ }^{1}$ Statistical Office of the Republic of Serbia - POPULATION, Comparative review of population rates from 1948-2002; The Census of Population, Households and Dwellings in 2011.

Table 2 Primary schools in Trgovište municipality with outposts ${ }^{2}$

\begin{tabular}{|c|c|c|c|c|c|c|}
\hline no. & School name & Address & Place & $\begin{array}{l}\text { no. of } \\
\text { classes }\end{array}$ & $\begin{array}{c}\text { no. of stu- } \\
\text { dents }\end{array}$ & $\begin{array}{c}\text { no. of } \\
\text { buildings }\end{array}$ \\
\hline 1. & $\begin{array}{c}\text { Žarko Zrenjanin } \\
\text { Uca }\end{array}$ & $\begin{array}{l}\text { Radovnica } \\
\text { (village) }\end{array}$ & Radovnica & 7 & 79 & 2 \\
\hline 2. & $\begin{array}{c}\text { Branko } \\
\text { Radičević }\end{array}$ & $\begin{array}{l}\text { Osme srpske udar- } \\
\text { ne brigade no. } 1\end{array}$ & Trgovište & 12 & 192 & 2 \\
\hline 3. & $\begin{array}{c}\text { Branko } \\
\text { Radičević }\end{array}$ & village Kozji Dol & Kozji Dol & 1 & 2 & 2 \\
\hline 4. & $\begin{array}{c}\text { Branko } \\
\text { Radičević }\end{array}$ & village Lesnica & Lesnica & 1 & 1 & 1 \\
\hline 5. & $\begin{array}{c}\text { Branko } \\
\text { Radičević }\end{array}$ & $\begin{array}{c}\text { village } \\
\text { Donja Trnica }\end{array}$ & Donja Trnica & 1 & 7 & 1 \\
\hline 6. & $\begin{array}{c}\text { Branko } \\
\text { Radičević }\end{array}$ & village Crnovce & Crnovee & 1 & 3 & 1 \\
\hline 7. & $\begin{array}{c}\text { Branko } \\
\text { Radičević }\end{array}$ & village Zladovce & Zladovce & 1 & 1 & 1 \\
\hline 8. & $\begin{array}{c}\text { Branko } \\
\text { Radičević }\end{array}$ & $\begin{array}{c}\text { village Siroka Pla- } \\
\text { nina }\end{array}$ & \begin{tabular}{|c|}
$\begin{array}{c}\text { Siroka Plani- } \\
\text { na }\end{array}$ \\
\end{tabular} & 1 & 2 & 1 \\
\hline 9. & Vuk Karadžić & Donji Stajevac & \begin{tabular}{|c|}
$\begin{array}{c}\text { Donji Staje- } \\
\text { vac }\end{array}$ \\
\end{tabular} & 6 & 27 & 6 \\
\hline
\end{tabular}




\begin{tabular}{|l|c|c|c|c|c|c|}
\hline 10. & Bora Stanković & Novo Selo bb & Novo Selo & 10 & 43 & 1 \\
\hline 11. & Bora Stanković & Petrovac Novo selo & Petrovac & 1 & 1 & 1 \\
\hline 12. & Bora Stanković & village Barbace & Barbace & 1 & 2 & 1 \\
\hline 13. & Bora Stanković & village Sajince & Sajince & 1 & 1 & 1 \\
\hline 14. & Bora Stanković & village Margance & Margance & 1 & 1 & 1 \\
\hline
\end{tabular}

${ }^{2}$ Official data from the site of the Ministry of Education,Science and Technological Development of the Republic of Serbia, available at: http://opendata.mpn.gov.rs/

Table 3 The only high school in the municipality of Trgovište ${ }^{3}$

\begin{tabular}{|c|c|c|c|c|c|c|}
\hline no. & School name & Address & Place & $\begin{array}{c}\text { no. of } \\
\text { classes }\end{array}$ & $\begin{array}{c}\text { no. of } \\
\text { studen- }\end{array}$ & $\begin{array}{c}\text { no. of } \\
\text { buildings }\end{array}$ \\
\hline 1. & $\begin{array}{c}\text { The Technical } \\
\text { High School } \\
\text { „Milutin Bojić“ }\end{array}$ & 15. septembar bb & Trgovište & 5 & 113 & 1 \\
\hline
\end{tabular}

${ }^{3}$ Official data from the site of the Ministry of Education,Science and Technological Development of the Republic of Serbia, available at: http://opendata.mpn.gov.rs/

Данијела Здравковић

Синиша Стојановић

Звездан Савић

\section{МЛАДИ СПОРТИСТА О ЖИВОТНИМ МОГУЋНОСТИМА И СПОРТУ У РУРАЛНИМ ПОДРУЧЈИМА ЈУЖНЕ СРБИЈЕ - КВАЛИТАТИВНИ ПРИСТУП (ОПШТИНА ТРГОВИШТЕ)}

Сажетак: Рад је настао из потребе да се укаже на друштвени положај младих спортиста и значај који социјализаџија младог руралног становништва има за ревитализацију пограничја Јужне Србије. У уводном делу рада говори се о испитиваном пограничном подручју јужне Србије, које се током XX века развијало под јаким утицајем ширих друштвених, политичких и економских чиниоца који су детерминисали ьегов демографски развој. Захваљујући томе, становништво пограничног подручја је у XXI век ушло са три дугорочна демографска процеса и то укупном депопулацијом (падом броја становника), природном депопулачијом (више умрлих од живорођених) $u$ демографским старењем, чему ваља придружити изражене ефекте деиндустријализаџије. Предмет истражнивьа: аутори су обрадили феномен очуваности идентитета локалног становништва у пограничној општини Трговиште, исптујући осећаје младих спортиста на селу о юиховој припадности 
друштву. Осећај ове припадности, зависи од четири система соџијалне укључености (сочијалне инклузије) (Jentasch and Shucksmith 2004). Испитивана погранична општина је на крајњем југоистоку Републике Србије и уз саму гранииу са Македонијом, а граничи се са опитинама Босилеград, Врање и Бујановач. Методологија рада: У раду је примењен квалитативни стил истраживања, а подаџи су прикупљани применом методолошких Упутства и прочедура за прикупьағе података у пограничним општинама источне $и$ југоисточне Србије у оквиру пројекта „Одрживост идентитета Срба и националних мањина у пограничним општинама источне и југоисточне Србије“ (ОИ 179013), који се реализује на Универзитету у Нишу - Машински факултет, а финансира га Министарство просвете, науке и технолошког развоја РС. Резултати истражнивања: Рад осветљава предности и недостатке живљена у руралним заједницама општине Трговиште из визуре младог руралног становника (Марка Трајковића, студента Универзитета у Нишу). Продубљеним интервјуом издвојене су социолошке карактеристике о стилу живота и ограничењима у плановима за будућност у испитиваном руралном подручју. Препознавањем актуелних демографских, сочијалних $и$ економских трендова, етничких и образовних различитости у јужном српском граничном појасу, ауторка је приступила испитивању квалитета свакодневног живота младих становника, који представљају један од виталнијих фактора обнове развоја села у пограничном руралном простору. Закључак: Истраживањем смо утврдили да су животна очекивања младих становника испитиваног руралног подручја обликована кроз њихова мишьења о селу као повољном (односно неповољном) оквиру за испуњење юихових животних амбиција. Упркос скромном уделу младих у Трговишту, они су пуни оптимизма. Али, управо, тај сочијални и хумани капитал је потребно искористити. Остаје нам нада да ће овај скромни прилог иницирати неопходна истраживања стилова живота младих у пограничним областима јужне Србије, с тенденцијом унапређивања квалитета живота млађег становништва и стицања повољнијих социо-економских предуслова за ревитализаџију тих простора у новом таласу модернизуације Р. Србије.

Кључне речи: обнова села, студент Факултета за спорт и физичко васпитање УНИ,Трговиште, Марко Трајковић.

Примљено: 24. 12. 2016. године.

Одобрено за штампу: 03. 02. 2017. године. 